\title{
O DRAMA PÚBLICO DE RAUL POMPEIA Sexualidade e política no Brasil finissecular
}

\section{Richard Miskolci \\ Fernando de Figueiredo Balieiro}

\section{À Notícia e ao Brasil declaro que sou um homem de honra. RAUL POMPEIA - 25-12-1895}

Salta aos olhos este bilhete deixado pelo jovem e talentoso intelectual no natal de 1895 , quando se matou com um tiro no coração, surpreendendo seus contemporâneos e entrando para a história de forma trágica. Nacionalista sintonizado com a vertente jacobina da Primeira República, envolveu-se em contenda política com outros intelectuais entre 1892 e 1895 e, impossibilitado de se defender à altura dos ataques dos adversários, sucumbiu ao desespero. O suicídio de Raul Pompeia (1863-1895) terminou por corroborar as especulaçōes sobre seu suposto caráter doentio e "esquisito", julgamento que marca suas narrativas biográficas e as críticas de suas obras há mais de um século.

Artigo recebido em maio/2010

Aprovado em novembro/2010
Questionando os julgamentos ou as conjecturas sobre o "caráter" de Pompeia, é possível reconstituir historicamente e analisar de forma sociológica o que sua tragédia oculta sobre os valores, os ideais e os fantasmas da sociedade brasileira de então. Seu lacônico bilhete suicida revela o caráter público de seu drama pessoal. Nele, tem como interlocutor não alguém próximo, um familiar ou amigo, mas a esfera pública unificada na referência a um jornal e à nação brasileira. Exposto ao escrutínio de todos, envergonhado, demanda, com seu derradeiro sacrifício, o reconhecimento social de sua honra.

Segundo J. Pitt-Rivers (apud Rohden, 2006) é possível compreender a honra como o valor que uma pessoa tem a seus olhos e aos olhos de seus contemporâneos por meio da confirmação de determinadas formas de conduta. ${ }^{1}$ Ou seja, a honra liga os ideais coletivos à sua reprodução nos comportamentos individuais. A vergonha, por sua vez, revela-se na preocupação com a reputação, o que 
faz a pessoa sensível à pressão exercida pela opinião pública. Honra e vergonha não são opostas, pois a falta de vergonha é que equivale à desonra. Assim, são dois lados da mesma regra de valorização social que define os ideais de uma sociedade, consolidando sua unidade.

Além de indissociáveis, honra e vergonha variam histórica e culturalmente. Raul Pompeia, enredado em um rígido sistema de valores morais, buscou recuperar a honra perdida em um drama pessoal que demonstra como - a despeito de seus idealizadores na teoria social - a esfera pública é um espaço de reforço de normas baseado na publicização do privado. ${ }^{2} \mathrm{O}$ caráter dramático da tragédia individual nubla suas causas coletivas, em particular a ruptura normativa que se faz ao trazer a público certas suspeitas sobre a vida privada de alguém. A suspeita, nascida do rumor e da fofoca, torna-se ameaça e - nos casos mais graves - motivo de horror coletivo. No caso de Pompeia ou, para fugirmos a qualquer personalismo enganador, no caso de seu drama público, a polêmica em que se envolveu tinha motivação política, mas - algo que pretendemos esclarecer - se desenvolveu na gramática da sexualidade e do gênero.

Roberto Ventura (1991) sublinha o fato curioso de que, no Brasil de fins do século XIX, dominava um clima acirrado de desafio e disputa política no meio intelectual. Estas polêmicas traduziam disputas simbólicas do período sobre um ideal de nação que se criava junto com a consolidação do regime republicano. Um fato crucial, mas pouco explorado, é que tais polêmicas se davam entre homens de elite. A associação entre nação e masculinidade vinculava-se à preocupação com o caráter modelar destes homens, de sua suposta missão viril de representar e encarnar os ideais políticos que se confundiam com rígidos valores morais. Neste sistema de valores normativos, a adesão aos ideais era premiada no mesmo grau em que era temida e perseguida qualquer suspeita de dissidência. Percebe-se, assim, o enquadramento em que se inseriu Pompeia tanto em seu engajamento político quanto em sua criação artística.

Raul Pompeia trouxe ao discurso literário relações "escabrosas", na qualificação utilizada pelo jornal em que publicou seu romance O Atenen (1888), no qual descreve relaçôes entre meninos como parte da "imoralidade" presente na decadente ordem imperial. Movido por intenções de crítica política, o autor acabou retratando uma nova forma de compreensão da masculinidade e das relações afetivo-sexuais que se impunha aos homens brancos da elite nacional.

Sua obra-prima estampava a primeira página do distinto jornal carioca Gazeta de Notícias, no ano emblemático de 1888, apresentando as memórias de Sérgio sobre seu tempo de aluno, naquele que descreve como o internato da "fina flor da mocidade brasileira", instituição dirigida por Aristarco Argolo de Ramos, fictício pedagogo de importantes contribuiçôes à educação nacional. $\mathrm{O}$ romance apresenta as experiências e os sentimentos do protagonista-narrador em meio à disciplina opressiva do diretor e seus bedéis. Contexto em que ganham centralidade as relaçôes afetivas entre os estudantes, apresentadas como o polo vexaminoso do qual todos deveriam se afastar. Também expóe de forma contundente as violências em que se apoiava esta pedagogia do sexo voltada à formação dos homens das classes dominantes.

Narrativa densa sobre (homos)sexualidade, ela se insinua como um fantasma em torno do qual giram as preocupaçôes do diretor, a organização do internato e o verdadeiro aprendizado a que são submetidos os estudantes. Araripe Jr. (1978), primeiro crítico do romance, o compreendeu - em tom darwinista - como um livro de resistência ao meio em que Sérgio seria um resistente ao horror da "sequestração sexual" do internato, não sem surpreender o leitor com suas "mórbidas" sensaçôes íntimas, leia-se, suas menções indiretas às interaçôes homoeróticas que vivera ali. Mário de Andrade (1974) sublinhou o conteúdo autobiográfico do livro, interpretando o romance como uma obra de vingança contra o ambiente educacional marcado por uma pedagogia vivenciada pelo próprio autor.

Dentre as análises contemporâneas, a de Alfredo Bosi (1988) ressalta como a caracterização do "meio", discutida pelos outros críticos, toma uma forma de interpretação histórica, sendo a violência vivida no internato, apesar de não se resumir a isto, representativa do Segundo Império. Mais recentemente, Silviano Santiago sublinhou a complexidade do enredo de $O$ Ateneu, apontando as in- 
suficiências de uma interpretação unilateral: "cada análise do romance permitia uma outra interpretação, oposta ou lateral, igualmente válida e justa. Todos os críticos iam tendo razão, sem a ter inteiramente" (Santiago, 2000, p. 67). Para ele, adentrar integralmente na obra só é possível a partir das contradiçōes inerentes a ela.

A leitura de $O$ Ateneu, para além de sua apreciação estética, pode ser feita de forma sociológica se encararmos o romance como um "arquivo histórico" que revela aspectos importantes das mudanças culturais e políticas pelas quais passava a sociedade brasileira de fins do século XIX. ${ }^{3}$ A narrativa de Pompeia capta tensões e ambiguidades sociais que percorrem desde a vida dentro de um internato de elite até as relações mais amplas da esfera política nacional. Sua importância é mais bem compreendida quando consideramos o período de publicação do romance, no ponto de viragem entre o Segundo Império e a proclamação da República.

$O$ Ateneu era publicado diariamente, mas foi interrompido a partir do dia 14 de maio de 1888, para voltar quatro dias depois com o capítulo final em que o internato se dissipa em chamas. Durante a interrupção da narrativa, a Gazeta aparece tomada pela notícia da abolição da escravatura. No dia 18 , quando o romance volta às folhas do jornal, apresenta-se o episódio em que Américo, um furioso aluno recém-matriculado, incendeia a instituição prestigiada em solenidades pela princesa regente e outros representantes do Império. $\mathrm{O}$ nome do incendiário é revelador. Leila Perrone-Moisés (1988) aponta o simbolismo da morte de Franco e a revanche de Américo construídas a partir da oposição corrente na época - entre Europa e Monarquia e América e República.

$\mathrm{O}$ fogo que atravessa o educandário coincide com a culminação dos ânimos exaltados pela notícia dos dias anteriores. O passado imperial e escravocrata, com toda sua imponência, reduz-se a cinzas, imbricando a criação literária com a trajetória abolicionista e republicana de Raul Pompeia. Seu engajamento molda o romance, compondo a caracterização, por vezes burlesca, outrora pessimista, de um ambiente decadente e corrupto. Assim, constrói suas personagens da velha ordem social de forma que o poder exercido no internato - rodeado dos símbolos da monarquia - convida o leitor ao riso, sem deixar de revelar também o aspecto tenebroso que marca a vivência dos alunos. A atmosfera do colégio é de medo e tensão, assombrada pelo espectro das sexualidades divergentes à norma social que ganham - pouco a pouco - centralidade nas páginas do romance.

As relações entre os garotos corroboravam as valorações morais do período de Pompeia, no qual se vivia uma ordem política e social em decadência em que as experiências subjetivas refletiam a ordem política corrupta. Não obstante, O Ateneu carrega também marcas de uma "nova" sociedade que se formava no contexto em que era publicado. Seu desfecho aponta para a superação desta ordem degenerada do Segundo Império: o incêndio do internato por Américo. O colégio, que simbolizaria o velho, seria destruído pelo novo, representado pelo aluno recém-chegado cujo nome evoca a república como destino americano. O incêndio - evocando a imagem bíblica de Sodoma e Gomorra - aparece como uma catarse, a superação da corrupta e "perversa" vivência no internato (e na monarquia) por meio de uma "purificação" republicana.

É possível acessar, por meio de O Ateneu, uma pedagogia da sexualidade que se desenvolvia e se articulava às mudanças políticas, em particular uma nova forma de compreensão da nação brasileira, suas ameaças e desafios. Dentre eles, destacava-se o temor da degeneração, o qual rondava com o espectro da recém- "descoberta" homossexualidade, as relações entre os homens brancos de elite na sociedade brasileira do fin-de-siècle.

Em termos foucaultianos, este período foi marcado pela emergência, em solo brasileiro, do dispositivo histórico da sexualidade, o qual caracteriza as sociedades ocidentais modernas desde o século XVII, mas no final do século XIX se baseava na inserção do sexo em sistemas de utilidade e regulação social. O dispositivo tinha então várias frentes estratégicas, ${ }^{4}$ entre as quais a que mais interessa aqui é a crescente pedagogização do sexo da criança por causa dos perigos morais e físicos a que supostamente estariam expostas, o que afetaria diretamente a coletividade.

No que concerne à padronização e ao agenciamento do desejo, ganharam relevância as trans- 
formações nas relações sociais entre homens, especialmente homens brancos letrados, vistos como depositários das esperanças da nação. Jurandir Freire Costa (2004) observa que era patente a preocupação com os então chamados "homossexualismo de escola" e "homossexualismo de quartel". 5 De forma que obras literárias como O Ateneu (1888), Bom-Crioulo (1895) e até mesmo Dom Casmurro (1900) se revelam fontes preciosas para a análise e a compreensão dos temores e reações que a nascente ordem republicana buscou enfrentar. ${ }^{6}$

Sexualidade e política associam-se neste período em que a sociedade brasileira discutia a viabilidade de uma nação formada por um povo negro e mestiço. Unia-se ao amplo e conhecido debate sobre a miscigenação e o "branqueamento", um processo menos visível de naturalização de certas relaçôes em detrimento de outras, de forma que a história brasileira de então se insere - de modo particular e pouco explorado - na "naturalização" da heterossexualidade por meio do estabelecimento da homossexualidade como o princípio da diferença sexual e social, o que, no século XX, levaria a uma nova forma de compreensão da sexualidade baseada na individualização do desejo e na atribuição, a cada indivíduo, de uma orientação e uma identidade sexual.

Segundo David M. Halperin, a "invenção" da homossexualidade, no terço final do XIX, revelou-se fundamental na articulação da diferença, na produção social do desejo e na própria compreensão da subjetividade. Aos poucos, a homo e a heterossexualidade passaram a ser vistas como formas mutuamente exclusivas da subjetividade, consolidando uma das características centrais do dispositivo de sexualidade contemporâneo, qual seja, a forma como ele institui e mantém o binário hetero-homo (2000, pp. 112-113) no que hoje sintetizamos no termo heteronormatividade. Desenvolvido pela Teoria Queer,

[...] o conceito de heteronormatividade sintetiza o conjunto de normas prescritas, mesmo que não explicitadas, que marcam toda a ordem social e não apenas no que concerne à escolha de parceiro amoroso; alude, também, ao conjunto de instituiçôes, estruturas de compreensão e orientação prática que se apoiam na heterosse- xualidade. É toda esta ordem social que mostra como no par heterossexualidade/homossexualidade não há simetria, pois ele engloba díades como norma/desvio, regra/exceção, centro/ margem (Miskolci e Pelúcio, 2008, p. 7).

Possivelmente fugindo às intenções do autor, $O$ Ateneu insere-se e retrata a formação de nossa particular ordem heteronormativa, fundada na interdependência entre os polos hetero/homo. $\mathrm{O}$ primeiro polo, representativo do que se considerou natural, estendeu-se à esfera pública e foi tratado como sinônimo de saudável, enquanto o segundo foi relegado à esfera privada e visto como degeneração. A constituição simultânea - e interdependente - deste binário sexual fundamenta também a criação de um ideal de nacionalidade viril que marcaria a incipiente esfera pública no que toca aos debates políticos sobre a nação brasileira.

A seguir, empreenderemos uma análise que busca explorar a maneira pela qual a sexualidade se constituiu como um sistema de diferenças ${ }^{7}$ no Brasil finissecular alicerçado tanto em um nível macro, das instituições políticas, como em um nível micro, na constituição das subjetividades e dos desejos. Buscamos, assim, contribuir para superar uma divisão entre história privada e pública, mostrando como a constituição social das subjetividades é parte integrante e fundamental da história social e política.

Partiremos da análise de como a emergência do binário interdependente da hetero/homossexualidade marcou a inteligibilidade das relaçôes políticas no contexto brasileiro de fins do século XIX, por meio das imbricaçôes entre homossexualidade e o temor de degeneração nacional em $O$ Ateneu. A partir disso, pretendemos esclarecer as relaçôes pouco exploradas entre a crítica de Pompeia à disciplina opressiva nos colégios de elite e sua trajetória política marcada pela tragédia.

\section{"Há mulheres no Ateneu!": o espectro da degeneração sexual na elite brasileira}

O diagnóstico de degeneração nacional emergiu na crise do Segundo Império, contrastando com as expectativas de progresso encarnadas no 
projeto republicano já em gestação após a década de $1870 .^{8}$ A obra literária de Raul Pompeia é criada neste período, marcada por um contexto de declínio da ordem imperial e suas bases escravistas em meio à formação de centros urbanos com populações relativamente independentes dos setores senhoriais (Costa, 1999).

Segundo Dain Borges (2005), a produção literária brasileira e nosso nascente pensamento social de fins dos oitocentos são marcados por um diagnóstico social de degeneração que expressava temores de decadência moral, política e "racial". A degeneração era uma noção controversa, imprecisa e difundida internacionalmente nos diversos campos do saber: ora se referia ao meio social como um todo, ora servia para identificar indivíduos que ameaçariam a ordem estabelecida. O debate sobre a miscigenação e o espectro da sexualidade fora da norma relacionavam-se com estes respectivos "significados" da degenerescência. De forma esquemática, enquanto a miscigenação evocava as preocupações com o futuro de nosso povo, em especial as classes populares, a homossexualidade constituía-se como espectro dentro da elite.

Em 1882, o ainda estudante da Faculdade de Direito de São Paulo publica a novela Jóias da coroa na qual o diagnóstico de degeneração é o fio condutor. $\mathrm{O}$ enredo constitui uma paródia do inusitado roubo de jóias na corte que tomou as páginas da imprensa. As personagens e os lugares são construídos de forma a garantir aos leitores uma fácil identificação com o acontecimento real. No desenrolar do enredo, o escandaloso caso que vai parar na polícia é abafado, pois surgem indícios de que o provável ladrão possui vínculos com Duque de Bragantina - personagem inspirada em Pedro II. Além de corrupto, o Duque é descrito como asqueroso em seu comportamento adúltero. Nas páginas finais, a personagem é impedida por sua esposa de travar relações sexuais com uma moça que - sem saber - na verdade, era sua filha bastarda.

O Ateneu também é repleto de noções presentes no pensamento social e literário de seu período. Descrições sobre a perversão, a corrupção e a imoralidade são recorrentes na narrativa e, à primeira vista, correspondem estritamente às relações que se estabelecem dentro do microcosmo do internato. O repertório linguístico explorado pelo autor in- corpora princípios deterministas do darwinismo social $^{9}$ muito difundidos em seu tempo pela literatura naturalista. A incorporação deste referencial sustentava-se em uma crítica ao status quo monárquico, responsabilizando-o pelo cenário pessimista que se diagnosticava no contexto nacional.

$\mathrm{Na}$ palestra de Dr. Claudio, a análise dos descaminhos da nação desloca-se da perspectiva hegemônica marcada pelo determinismo racial ou climático para uma crítica moral do Império (cf. O Ateneu, p. 45). Silviano Santiago (2000) salienta que Dr. Claudio escapa às descrições pessimistas que o narrador faz das demais personagens, ${ }^{10}$ pois seus discursos expressam muito da visão de Pompeia sobre a Monarquia. No entanto, esta crítica republicana manifesta-se sobretudo por outros meios, em especial a forma como a experiência pedagógica no internato é vivida com terror, assim como o autor vincula a caricatura despótica de Aristarco com símbolos do regime. Sua figura poderosa é constantemente desacreditada em passagens que o associam comicamente às instituições imperiais, como na solenidade da distribuição bienal dos prêmios escolares, na qual ganha um busto coroado.

A caracterização satírica e despótica do diretor acompanha a composição de um ambiente de terror no colégio onde, em vez dos castigos físicos, infligia um controle exaustivo que marcava com o medo a vivência dos alunos. $\mathrm{O}$ temor insinuava-se não apenas pela tirania de Aristarco, mas por sua capacidade de imbuir nos meninos o horror ao espectro da perversão que os ameaçaria. O "meio" escolar é entendido por Sérgio como um "ouriço invertido", no qual se torna uma tarefa árdua escapar da "explosão divergente dos dardos", simbolizando as influências perniciosas do ambiente.

Destacam-se as "paixões, fraquezas e vergonhas" (O Ateneu, p.59) que se materializam nas interaçôes afetivo-sexuais entre os alunos do internato. Relações entendidas sob a lente da "perversão" ou "imoralidade" pela direção da escola e mesmo pelos meninos. Enquanto em Jóias da coroa a construção da degeneração se associa a uma sexualidade incestuosa vinculada ao imperador, em O Ateneu ela se apresenta nas manifestações de afetividade entre meninos. Em todo o romance, apenas um caso amoroso chega ao conhecimento de Aristar- 
co. $\mathrm{O}$ diretor ameaça punir os envolvidos, mas, em descrição evidentemente irônica do narrador, acaba absolvendo os "réus da moralidade" para salvaguardar as finanças da instituição.

A sexualidade expressa o contexto imperial "perverso" em O Ateneu, um contexto no qual a polaridade normal/patológico, amparada pelas ciências biológicas, vem substituir um regime de verdade antes assentado na religião, constituindo uma nova inteligibilidade. ${ }^{11}$ As ciências médicas, que se tornavam hegemônicas na leitura e intervenção na esfera social, criavam novas categorias "perversas" que serviam de limite para o que era considerado normal. Identidades, corpos, subjetividades e até mesmo instituiçôes passavam a ser categorizadas e controladas a partir desta díade interdependente.

A invenção da identidade homossexual foi aspecto fundamental neste processo. Como categoria psiquiátrica, ela se tornou um dos principais símbolos do patológico e o limite constitutivo do normal. A partir de sua criação, é possível dizer que o binário normal/patológico desdobra-se em hetero/ homo dentro de um esquema de interdependência que garante inteligibilidade (ou seja, aceitação ou rechaço) social. Tal esquema fundamenta-se em paralelo com outros binarismos como puro/impuro, moral/imoral, limpo/sujo, progresso/decadência.

A saturação de sexo no internato não só apresenta as formas de regulação da sexualidade no período, como também corrobora as representações correntes sobre a monarquia em decadência. ${ }^{12}$ Nesta linha, a categoria sexualidade funciona não apenas como criadora de identidades sociais, mas como categoria de conhecimento que se dirige também a instituições políticas. Daí afirmarmos que está presente em O Ateneu a "homossexualização" do Segundo Império, relacionando "imoralidade" e instituições monárquicas.

O espectro da homossexualidade masculina que rondava a elite branca no Brasil tinha paralelo em outras partes do Ocidente. $\mathrm{Na}$ Inglaterra e na Alemanha, por exemplo, ela passara a ser criminalizada e patologizada, reforçando as relações entre direito e medicina no que toca ao controle e à delimitação da sexualidade. Seu caráter não era apenas indesejável, antes fonte de verdadeiro horror e repulsa perceptível na forma como se evitava mencioná-la diretamente. Até seus defensores preferiam chamá-la de "o amor que não ousa dizer seu nome", de forma que seu interdito os levava a vivenciarem apenas na vida privada e de forma oculta, portanto no reino do segredo que - no século XX - passaríamos a denominar "armário". ${ }^{13}$

$\mathrm{O}$ interdito à homossexualidade estrutura o romance por meio da regulação subjetiva dos meninos. Aristarco, desde o dia da matrícula de Sérgio, sinaliza sua principal preocupação com os internos: a "imoralidade". Palavra pronunciada com "entonação especial, comprimida e terrível, que nunca mais esquece quem a ouviu dos seus lábios" (O Ateneu, p. 9), ela passaria a dominar os pensamentos de Sérgio: "Zumbia-me aos ouvidos a palavra aterrada de Aristarco [...]" (Idem, p. 13). No entanto, o terror que ela evocava demora a se tornar explícito em um processo em que o inominável se tornava ainda mais aterrador em seu potencial de abjeção.

A ameaça da "imoralidade" contra a qual o pedagogo dirigia rigorosamente seu internato estruturava seu sistema de vigilância exaustivo. Este controle constitui o núcleo do que Foucault (2007) denominou pedagogia do sexo, a qual visaria evitar os pretensos perigos degenerativos da sexualidade infantil. Em O Ateneu, esta nova pedagogia baseada no medo revela o aprendizado da recusa do desejo que passara a ser associado ao reino do patológico. De forma mais clara, o aprendizado inovador coordenado por Aristarco buscava inculcar, como imoral e abjeta, o que a sexologia do período começava a chamar de homossexualidade.

Segundo Halperin (2002), o controle das relações amorosas ou sexuais entre homens se intensificava por meio de sua recente associação simbólica com a ideia de inversão de gênero. ${ }^{14}$ No Ocidente como um todo, e de forma particular em nosso país, a "invenção" contemporânea da homossexualidade como algo repugnante e ameaçador, em suma, como abjeta, dependeu de sua identificação forçada com uma masculinidade "corrompida" pelo efeminamento, a qual encarnaria a imoralidade a que se refere Aristarco, a temida "perversão" sexual. ${ }^{15}$ Compreende-se por que, em $O$ Ateneu, feminizar e perverter são sinônimos.

Logo no início da entrada de Sérgio no internato, ele recebe os conselhos de seu experiente cole- 
ga Rebelo: "Os gênios fazem aqui dois sexos, como se fosse uma escola mista. Os rapazes tímidos, ingênuos, sem sangue, são brandamente impelidos para o sexo da fraqueza; são dominados, festejados, pervertidos como meninas ao desamparo". A partir de então, o colega mais experiente cita aqueles que compartilham "vícios" e "perversões” e, entre eles, repara em um: “"Esse que passou por nós, olhando muito, é o Candido, com aqueles modos de mulher, aquele arzinho de quem saiu da cama, com preguiça nos olhos... Este sujeito... Há de ser seu conhecido"”. Ressalta, enfim: "'Olhe; um conselho; faça-se forte aqui, faça-se homem. Os fracos perdem-se" (Idem, p. 14).

Candido ganha destaque com o desenrolar do enredo, quando Aristarco descobre uma carta reveladora de seu romance com o colega Emílio, em que assinava Candida. O diretor convoca os estudantes e expõe publicamente o caso "imoral": "Tenho a alma triste senhores! A imoralidade entrou nesta casa! Recusei-me a dar crédito, rendi-me à evidência... Ah! Mas nada me escapa... tenho cem olhos. Se são capazes, iludam-me! Está em meu poder um nome de mulher! Há mulheres no Ateneu, meus senhores!" (Idem, p. 65, grifo nosso).

No horário do almoço do dia seguinte, Aristarco, seguido de professores, bedéis e criados curiosos, começa a empreender o processo de investigação do "caso Cândido". Chama os envolvidos: "Levante-se, Sr. Cândido Lima... Apresento-lhes, meus senhores, a Sra. D. Cândida', acrescentou com uma ironia desanimada... 'Levante-se, Sr. Emílio Tourinho... Este é o cúmplice, meus senhores!"”. E em seguida, chamou os "auxiliares”: "'Estes são os acólitos da vergonha, os co-réus do silêncio!'”(Idem, p. 67). A atenção é focada no aluno Cândido. O próprio Emílio só é citado esta única vez e descrito como cúmplice. Mesmo tendo em conta que a relação homoerótica em si era "imoral" e digna de punição, a figura feminizada de Cândido era entendida como mais vexaminosa, corroborando as teses de inversão aceitas no período. Em outras passagens a figura feminina nos meninos era apresentada pelo narrador como "erro de conformação", "corruptas" ou "decaídas".

Visando combater a homossexualidade, a organização do internato ambiciona um controle exaustivo dos alunos; forma-se uma "pirâmide hierárquica" começando pelo diretor e passando pelos professores, bedéis e alunos vigilantes que constituem uma vigilância quase completa. É visível como nos envolvimentos amorosos de Sérgio com alguns de seus colegas faz-se necessário fugir dos mecanismos disciplinares. Durante seu primeiro envolvimento avalia: "Sanches, como os mal-intencionados, fugia dos lugares concorridos. Gostava de vaguear comigo, à noite, antes da ceia, cruzando cem vezes o pátio de pouca luz, cingindo-me nervosamente, estreitamente até levantar-me do chão" (Idem, p. 22).

A vigilância escolar revela-se meio importante para a consolidação da heteronormatividade não apenas por meio da interdição das relações entre os meninos, antes pelo estabelecimento do binário hetero/homo, de forma a tornar o primeiro natural e respeitável por meio da construção do que supostamente o ameaçaria como algo repugnante e impuro. Assim, a homossexualidade, pelos meios os mais diversos, não seria (nem poderia) ser realmente eliminada, antes relegada às sombras e ao segredo constituindo os limites negativos da desejada heterossexualidade, a qual adquiria visibilidade, respeito e, por isso mesmo, era incentivada e ensinada de forma a mascarar seu caráter compulsório. Além disso, o aprendizado da heterossexualidade confundia-se com um adestramento de gênero em que o "homem de verdade" deveria não apenas se relacionar com mulheres, mas, antes de tudo, estar no topo de uma hierarquia de poder, ser dominador, viril, em suma, sinônimos da época que constituíam a masculinidade em si mesma.

As duas primeiras relações de Sérgio com outros garotos tinham em comum o fato de serem relações de proteção marcadas por uma hierarquia entre os envolvidos. Sanches era vigilante e contava com sabre de pau. Sérgio, protegido, sentia-se como parte do "sexo artificial da fraqueza" sobre o qual alertara Rebelo. A relação entre os dois se esvazia após a tentativa de aproximação de Sanches, que é descrita com repulsa (Idem, p. 22). A segunda relação se dá com Bento Alves, um estudante valente que detivera um assassino no internato. A relação entre os dois era marcada pela proteção de Bento: "no recreio não andávamos juntos; mas eu 
via de longe o amigo, atento, seguindo-me o seu olhar como um cão de guarda"; "soube depois que ameaçava torcer o pescoço a quem pensasse apenas em me ofender; seu irmão adotivo!" (Idem, p. 44). A díade masculino e feminino molda estas relações de proteção como corrobora a confissão de Sérgio sobre seus sentimentos por Bento: "estimei-o femininamente, porque era grande, forte, bravo; porque podia me valer; porque me respeitava, quase tímido, como se não tivesse ânimo de ser amigo" (Idem, ibidem).

Estas relações entre meninos marcadas por uma hierarquia de gênero (masculino/feminino) eram comuns na época entre adultos e constituíam a díade formada por homens viris, chamados de fanchonos, com os "frescos", uma identidade social que vinculava padrôes de gênero com comportamento sexual. James N. Green descreve os que encarnavam esta figura como aqueles que "passariam a usar roupas e estilos que serviam de indicativos de suas predileçôes sexuais e projetavam imagens efeminadas a fim de veicular sua disponibilidade para interaçôes sexuais com outros homens" (2000, p. 106). Na época, a figura do "fresco" era recorrente em charges de jornal ou mesmo em teses médicas, enquanto, curiosamente, há uma quase ausência de documentos sobre os fanchonos: "A aparente masculinidade dos fanchonos os protegia das prisões e dos médicos, advogados e outros voyeurs responsáveis pela maior parte da documentação escrita sobre homoerotismo na belle époque brasileira" (Idem, p. 71).

$O$ Ateneu permite acessar como certas relações entre jovens se desenrolavam e as categorizaçôes sociais acionadas para as compreender. Um ponto alto da narrativa é quando se explicita a aversão dirigida a elas. Trata-se do momento em que a relação entre Sérgio e Bento Alves é abalada pelo caso Cândido, e depois, se transforma consideravelmente. Vemos em formação, o que foi chamado por Sedgwick de homofobia, ${ }^{16}$ a recusa subjetiva do desejo homoerótico que marcou as relações entre Sérgio e Bento Alves - assim como a anterior com Sanches - por meio da incorporação do desprezo social perante sua manifestação. A compreensão do erotismo entre homens como o reino do impuro e do abjeto leva os que o vivenciam a interpretarem sua amizade como "uma situação prolongada de vexame", como um "sacrifício" até a relação terminar de forma violenta, em um ataque violento de Bento contra Sérgio, aquele por quem nutria desejo e, após o caso Cândida, encarnava a temida abjeção (Pompeia, O Ateneu, p. 66).

Percebe-se, literalmente em ação, o resultado da pedagogia do sexo a que eram submetidos os meninos de nossa elite. A relação entre eles não apenas cessa, mas é recusada com nojo e violência, deixando entrever a formação subjetiva de Bento. Judith Butler elucida: "o sujeito é constituído através da força da exclusão e da abjeção, uma força que produz um exterior constitutivo relativamente ao sujeito, um exterior abjeto que está, afinal, 'dentro' do sujeito, como seu próprio e fundante repúdio" (1999, p. 156). É este o cerne "abjeto" constituído em Sérgio que emerge diante dos olhos de seu antigo protetor, Bento Alves, de forma que seu repúdio do "efeminamento" que vê no outro (Sérgio) marca também sua adesão à masculinidade hegemônica.

Após esse episódio central em sua "formação", Sérgio inicia uma terceira relação marcante em sua vida de estudante. Egbert é o aluno com quem Sérgio passaria a se envolver profundamente em uma relação distinta das anteriores por ser marcada pela mutualidade. Entre eles, não havia um protetor e um protegido. As ideias da igualdade e da reciprocidade definem a relação entre os amigos (O Ateneu, p. 70).

A relação entre Sérgio e Egbert dava-se nos limites da amizade apaixonada. ${ }^{17}$ Por que tal proximidade não causou estranheza entre os colegas? Por que não virou chacota dos outros alunos? Por que não tinham que variar de atitude diante de bedéis, tampouco se preocuparem com o aparato disciplinar do colégio, buscando lugares escondidos? Se a organização disciplinar do colégio visava combater a "imoralidade" que se manifestava nas relaçōes entre garotos, por que tal relação não foi incluída no rol de preocupações de Aristarco?

Como afirma Sedgwick (1985), o que se considera como sexual é variável de sociedade para sociedade segundo suas relações de poder. Em um contexto no qual as relações entre pessoas do mesmo sexo eram inteligíveis a partir da polaridade mascu- 
lino/feminino, a entre Sérgio e Egbert não era compreendida enquanto provida de erotismo. Isto indica que, no final do século XIX, a relação entre homens era vista como sexualmente perigosa quando "desigual", pois apenas na desigualdade entre os gêneros residiria o erotismo. Enfim, o que se temia não eram as relações em si, antes o modelo em que elas se davam no que toca ao poder. Relações de proteção relegavam um dos homens à inferioridade associada ao feminino e, por isso, eram perseguidas.

Em fins do XIX, em todo o Ocidente, há registro de que as amizades masculinas passaram a ser progressivamente fiscalizadas. Foucault afirma que a decadência histórica da amizade masculina está ligada à emergência da problemática homossexual, ao surgimento da questão "o que dois homens fazem quando estão juntos?” (2004, pp. 272-273). A suspeita de que pudessem fazer sexo ou, pior, se apaixonarem, se instalara no seio das relaçôes entre homens e passara a definir seus limites por meio do espectro da homossexualidade, cuja recusa subjetiva passaria a ser o fundamento da heteronormatividade.

A conjunção entre masculinidade feminizada e homossexualidade verificou-se muito mais abrangente do que um meio regulador das relaçōes afetivas entre homens. A identificação e o controle de um Outro feminizado, pervertido e "imoral" se relacionava diretamente com a construção da identidade masculina hegemônica. O Ateneu é documento importante para a compreensão de como a abjeção foi construída pelo fantasma do efeminamento de forma que a criação de um Outro abjeto permitiu - de forma menos visível - a criação do sujeito hegemônico.

O abjeto é algo de si próprio pelo que alguém sente horror ou repulsa como se fosse sujo ou impuro, a ponto de que o contato com isto seja temido como contaminador e nauseante. No caso da formação dos meninos, este caráter abjeto era atribuído ao desejo por alguém do mesmo sexo, já que até mesmo a insinuação da homossexualidade equivalia à ameaça do "efeminamento" e, portanto, da condenação social. Assim, sua formação dentro da masculinidade dependia da incorporação do nojo por esta forma de desejo.

Tal repúdio pode ser percebido no conselho do experiente colega Rebelo ao novato Sérgio de "tornar-se homem e não se perverter", o qual era concretizado nas afirmações de virilidade entre os alunos que buscavam afastar o espectro do efeminamento, aproximando-se de uma masculinidade hegemônica, ou seja, daquela socialmente valorizada e que subordina outras formas de masculinidade. ${ }^{18}$ Nesse sentido, a educação no internato revela-se a construção da virilidade por meio de um mimetismo de violências que, em nossa sociedade, segundo Daniel Welzer-Lang, se inicia subjetivamente e, progressivamente, se dirige a outros homens (2001, p. 463$).{ }^{19}$

Retrato revelador desse aprendizado, o romance fornece elementos para compreender o tom violento das polêmicas da época, assim como elucida as regras dentro das quais estas disputas se desenrolavam. Em um sistema de valores em que honra era indissociável de virilidade, ou seja, dos padrōes de gênero e sexualidade vigentes, a disputa política mesclava-se à contenda elitista sobre conformação e representatividade em relação aos ideais normativos que definiriam a nação brasileira.

\section{Em defesa da honra: o suicídio de Pompeia}

As demandas de virilidade retratadas em $O$ Ateneu auxiliam a compreender o drama público que - de forma trágica - marcou os últimos anos da vida de seu autor. Pompeia adentrou na esfera de polêmicas marcada por ofensas e pela violência em que se tecia o debate intelectual e político da época, posicionando-se como defensor público do presidente Floriano Peixoto.

A criação de um romance em que desenvolvera uma crítica à monarquia por meio de um retrato da educação da elite nacional expôs Pompeia à desconfiança de seus contemporâneos. Superada a monarquia, mantinha-se a mesma elite, permitindo que seu romance fosse lido como resultado de experiência biográfica do autor, verdadeiro produto de "revolta" contra sua própria classe. O que tornava tal vivência motivo de suspeita era a forma explícita com que o romance apresentava as violentas demandas sociais de virilidade da sociedade brasileira de fins dos oitocentos em um contexto em que a consolidação de uma masculinidade hegemônica 
pressupunha a identificação abjeta de seu Outro, o degenerado, isto é, o homossexual como efeminado ou "invertido".

Retrato não intencional desse processo, $O$ Ateneu fora recebido por muitos como uma ofensa à elite e como uma denúncia de sua corrupção interna. Pompeia era um entusiasta da vertente jacobinista da Primeira República, ou seja, defendia a participação popular na política e o estilo de governar quase ditatorial de Floriano Peixoto. Essas posições fizeram com que, para muitos, ele adquirisse um status suspeito, algo visível na forma como, em 8 de outubro de 1890, O Estado de São Paulo noticiou a futura participação do cronista caracterizado como o "esquisito novelista do Ateneu". Nas biografias mais antigas, como a de Rodrigo Octavio (1978), até a mais recente de Camil Capaz (2001), Raul Pompeia aparece como uma criatura estranha; desde suas características físicas como portador de um estrabismo exagerado, passando pelo seu recato sexual até a sua sensibilidade aguçada, os quais eram associados ao seu radicalismo político, seu nacionalismo exaltado e seu florianismo convicto.

Os contemporâneos caracterizavam Pompeia como nervoso, radical e estranho, de forma que sua imagem como "anormal" e suscetível permitia dissociá-los do autor de O Ateneu. Segundo Ari Adut, denúncias e escândalos adquirem potencial mortífero devido à forma como os envolvidos reagem à ameaça de contaminação, ou seja, do espectro da vergonha que - no caso - respingava naqueles que partilhavam com o talentoso escritor do valor máximo da nacionalidade como sinônimo de virilidade, ou seja, masculinidade heterossexual. Formados em colégios similares ou apoiadores de dietas educacionais que associavam a formação "viril" com a própria construção do caráter nacional encarnado na elite intelectual e política, não era de se estranhar que seus contemporâneos buscassem apresentá-lo como "patológico".

Como dito anteriormente, vigorava uma compreensão da política associada à conformação aos valores morais da época, mas, refinando esta constatação a partir da análise empreendida até aqui, isto se dava no enquadramento de relações de poder intra-elite. $\mathrm{O}$ alto status das elites dão significação maior aos seus atos e transgressões, daí também uma maior preocupação com sua imagem pública e o desprezo reservado àqueles que deixam entrever desvios morais ou falhas em sua organização interna. Assim, compreende-se como o criador de um romance que colocava em xeque a capacidade da elite brasileira de se autodisciplinar e corresponder às demandas de exemplaridade no comando político despertava suspeita dentro de sua classe e passava a viver sob a ameaça de perder seu reconhecimento.

A honra dos homens de elite era indissociável do reconhecimento de seu papel modelar, sua adesão indiscutível aos ideais coletivos, dentre os quais se destacava o nacionalismo. Pedro Paulo de Oliveira postula que a construção de uma masculinidade moderna viril é resultado de complexas elaborações culturais, dentre as quais destaca "a formação do Estado nacional moderno e a criação de instituições específicas, como os exércitos, resultando nos processos de disciplinarização e brutalização dos agentes nelas envolvidos" (2004, p. 19). Este ideal moderno é produto de uma série de deslocamentos do modelo medieval de masculinidade relacionado com os duelos entre os nobres e sua relação com a honra, "bem como à coragem e o sangue-frio para defendê-la” (Idem, p. 23). No século XIX, criou-se uma imbricação entre masculinidade e nacionalismo de forma que o sacrifício pela pátria se tornou um atestado máximo de masculinidade, notadamente em períodos de guerras: "A capacidade de suportar os flagelos da guerra, como dor, fome, frio, mutilações, encarando impassivelmente a concreta possibilidade da morte, só poderia ser mantida se estivesse presente a ideia de que o verdadeiro homem viril era aquele que colocasse sua força de resistência a serviço de uma causa de maior valor [...]” (Idem, p. 31)

Esta concepção de masculinidade viril impunha-se no Brasil em meio a contendas políticas e intelectuais de caráter enganosamente personalistas: "polêmicas surgidas de questôes secundárias se desviavam para debates de erudição e defesas da honra, em que o desafiante buscava provar sua 'superioridade' sobre o oponente" (Ventura, 1991, p. 79). A defesa da honra era algo que se colocava com muita força: "das ameaças e xingamentos, os adversários chegavam a processos de difamação nos tribunais e mesmo ao suicídio, recurso extremo na defesa da honra ultrajada" (Idem, ibidem). 
À primeira vista, essas histórias poderiam ser interpretadas como resultado de nosso atraso institucional, afinal as instituiçōes burguesas, que permitiriam canais formais para a compensação dos conflitos, ainda não estavam consolidadas. Mas um olhar comparativo com o que se passava em outros países, como a Inglaterra, permite perceber que - na verdade - o que se passava nestas paragens tropicais se inseria no fenômeno dos escândalos e dramas públicos, os quais são regidos por uma lógica coletivista e definidos pelo exercício da justiça popular. ${ }^{20}$ Honra, virilidade e nacionalismo passavam a ser associadas e reconhecíveis de forma que qualquer suspeita sobre um desvio da norma sexual expunha o homem à ameaça de uma nova forma de desonra pública, a vergonha como marca da abjeção sexual.

Vivia-se o período de edificação da recente República. Pompeia, nacionalista fervoroso, posicionava-se em prol da unidade nacional em face dos interesses econômicos de países estrangeiros e das "ameaças" separatistas internas por meio da defesa apaixonada de Floriano Peixoto. Assim se desenrola sua polêmica com Olavo Bilac e Luís Murat, críticos do governo do "marechal de ferro".

A polêmica teve início em 1892 quando Pompeia defende Floriano no episódio em que reprimiu violentamente a "Revolta da Armada" - promovida por unidades da marinha contra o governo, que se uniram aos federalistas do Rio Grande do Sul - na Fortaleza de Santa Cruz de Santa Catarina. Em resposta, Olavo Bilac publicou artigo no jornal $O$ Combate ofendendo o jovem escritor: "Talvez seja amolecimento cerebral, pois que Raul Pompeia masturba-se e gosta de, altas horas da noite, numa cama fresca, à meia luz de veilleuse mortiça, recordar, amoroso e sensual, todas as beldades que viu durante o seu dia, contanto em seguida as tábuas do teto onde elas vaporosamente valsam" (Acervo da Biblioteca Nacional, 9/3/1892). Pompeia defendeu-se em artigo do Jornal do Commercio, revidando a ofensa: "o ataque foi bem digno de uns tipos, alheados do respeito humano, licenciados, marcados, sagrados para tudo - pelo estigma preliminar do incesto" (Idem, 15/3/1892).

A divergência política foi trazida ao discurso na gramática da sexualidade com referência às identidades sexuais do masturbador e do incestuoso maculando a honra dos envolvidos. Encontraram-se nos dias seguintes: "houve safanōes de parte a parte, insultos, e a intervenção pronta dos amigos que afastaram os brigadores, conduzindo-os para longe do local" (Capaz, 2001, p. 197). A afirmação da masculinidade viril era a forma de espantar o espectro da desonra. "Só a sangue isso pode acabar" (Octavio, 1978, p. 214), teria dito Pompeia a seu amigo Rodrigo Octavio e logo o duelo foi marcado.

No passado, segundo Oliveira, o que importava nos duelos, antes da vitória, era a bravura do enfrentamento: "As disputas muitas vezes deixavam marcas e cicatrizes para o resto da vida. Alguns não escondiam o orgulho de possuí-las e assim, não raro, elas se transformavam em verdadeiros troféus, inscritos nos corpos, símbolos de sua dignidade, atestado de destemor obtido e valorizado, inclusive, pelos perdedores" (2004, p. 25). Com o aburguesamento da sociedade, a permanência dos duelos se rearticula: "a ênfase na bravura, na ousadia e no destemor desloca-se paulatinamente para a questão da firmeza, do autocontrole e da contençãa" (Idem, ibidem). Assim, aparecem novos códigos, como o aperto de mãos no final do ritual.

No dia da realização do duelo entre Pompeia e Bilac, o comandante Francisco de Matos, uma testemunha escolhida, fez apelo para que os duelistas não começassem o embate. Houve um aperto de mãos sinalizando um acordo e, a despeito dos ânimos terem se esfriado, biógrafos afirmam que o florianista persistiu sentindo-se desonrado até que a polêmica se reativasse após o enterro do ex-presidente Floriano em 29 de setembro de 1895, no qual Pompeia proferiu discurso apologético a seu nacionalismo. Isto foi reconhecido como um desrespeito ao presidente em vigor, Prudente de Morais.

Não tardou para que Pompeia fosse demitido do cargo de diretor da Biblioteca Nacional e Olavo Bilac escrevesse, em tom sarcástico e ofensivo, sobre o fato. Pompeia defendeu-se no jornal O Paiz, no dia 3 de outubro, divulgando um resumo de seu discurso e afirmando que não ofendera o presidente e teria versado unicamente sobre proposições de natureza doutrinária.

Luís Murat, em artigo intitulado "Um louco no cemitério" no jornal O Commércio de São Paulo, 
defende o afastamento de Pompeia e conclui seu artigo de forma desmoralizadora nos padrōes da época, voltando ao assunto do duelo não ocorrido. Sobre a defesa de um governo autoritário, como o de Floriano, Murat opinou: "Ora, já vê o Sr. Dr. Raul Pompeia, que essas bravatas demagógicas não lhe ficam bem. O que me parece é que se trata de um caso de doença moral. $\mathrm{O}$ jacobinismo é um fenômeno mórbido, tão profundamente característico como o do niilismo russo" (Acervo da Biblioteca Nacional, 16/10/1895).

A ofensa aqui é construída de forma a unir covardia e "jacobinismo" como expressōes de uma doença moral que teria Raul Pompeia. Apenas em dezembro o escritor teve ciência do artigo na folha paulistana. Rodrigo Octavio (1978) afirma ter o autor escrito uma réplica violenta entregue no dia 24 de dezembro e não publicada pelo Jornal do Commercio. O escritor, sentindo-se rejeitado pelas gazetas e humilhado publicamente, mata-se no dia de Natal. O suicídio do autor corroborou interpretaçôes doentias sobre sua pessoa, como na matéria do Jornal do Commercio publicada um dia após sua morte:

Em Raul Pompeia, havia effetivamente -, e quantos o conhecerão poderão bem, dar testemunho disto -, uma vibratilidade nervosa excessiva, superaguda, quase mórbida. A sua retina intellectual era de uma impressionabilidade exaggerada, e para os pontos affectados desta visão em que se retratarão as cousas e factos, prodigosamente augmentados, elle se concentrava inteiramente, deixando-se absorver, aniquilar por completo (Acervo da Biblioteca Nacional).

A figura doentia atribuída ao escritor permitia associar suas distintas experiências como ativista engajado ligado às figuras mais radicais do abolicionismo paulista, nacionalista e florianista fervoroso com o autor de um romance que retratara os "desvios" na formação de nossos homens de elite. Aquele que diagnosticara a monarquia como degenerada teve, por fim, este diagnóstico voltado contra si mesmo, já que a figura do degenerado - acreditava-se - seria reconhecível em estigmas físicos como estrabismo, mas, acima de tudo, em manifestações "mentais" como histeria, egoísmo exagerado, pessimismo, impulsividade e falta absoluta de noção sobre o certo e o errado (Hawkins, 1997, p. 219; Miskolci, 2005, p. 18).

Longe de assumir esta perspectiva afinada com as teorias psiquiátricas daquele tempo, ressaltamos como estes modelos de inteligibilidade faziam parte de amplas pressões sociais que o predispuseram ao suicídio. A imagem pública do escritor de $O$ Ateneu encontrava-se fragilizada, especialmente nos últimos momentos de sua vida. Não combater um ofensor aceitando uma trégua antecipada e depois não ter a oportunidade de responder a uma ofensa de covardia que circulou em proeminente jornal da imprensa nacional significava não ser "viril" como se esperaria de um homem público como Pompeia. Além disso, a afronta à sua masculinidade associava-se a um temor da época corroborado pela revelação feita décadas depois por seu único amigo próximo, Rodrigo Octavio, de que o jovem procurara o ilustre médico Dr. Alfredo Camilo Valdetaro e tivera atestada "manifesta e irremediável deformidade sexual" (1978, p. 199).

Vale contextualizar o ano da morte de Pompeia: 1895 . Em 25 de maio deste mesmo ano Oscar Wilde foi condenado por "homossexualismo" a dois anos de prisão com trabalhos forçados. Ao mesmo tempo que o caso se tornou internacionalmente conhecido, introduzindo o tópico homossexual na esfera pública, no Brasil, foi lançado Bom crioulo, polêmico romance de Adolfo Caminha que narra a relação consumada sexualmente entre um branco e um negro. O livro escandalizou o público letrado ao explicitar de forma associada os temores sociais de sexualidade homoerótica e inter-racial. Culminando ano tão profícuo em escândalo, ocorre o suicídio de Pompeia, autor cuja principal obra evidenciara controversas relações entre sexualidade e política.

Luiz Labre, no quarto aniversário da morte do escritor, publicou artigo no folhetim $\mathrm{O} A r c h i-$ vo Illustrado (Arquivo do Centro de Estudo Afrânio Cuoutinho, UFRJ, 25/12/1899), revelando "infâmias" direcionadas a Pompeia em seu círculo próximo, as quais, juntamente com o ofensivo artigo de Luís Murat, também teriam contribuído 
para a sua morte prematura. Pompeia era alvo de escárnio dentro de seu grupo de amigos. Por que a perseguição a um autor e cronista tão respeitado por seu trabalho? As acusações "em tom de brincadeira” apontavam para uma característica sui generis do autor na visão de seus amigos: nunca havia se envolvido com mulheres. ${ }^{21}$ Seus biógrafos ressaltam seu caráter persecutório dentro dos ambientes masculinos de que participava. Noutra lente, hoje reconheceríamos o abuso moral sofrido pelo talentoso jovem.

A pressão social para incorporar a masculinidade hegemônica fincada em uma vida heterossexual termina por se materializar no maior ato de violência contra si mesmo. Neste drama público, o que menos interessa é saber a real sexualidade do escritor, antes a força do espectro da degeneração sexual na elite brasileira de então. Diante dele, o autor de O Ateneu buscou - por meio do suicídio - virilizar-se e resgatar a sua honra. Muitos artigos de jornal no dia seguinte destacaram o caráter "honrado" da pessoa do escritor brasileiro e enfatizaram sua importância nacional, julgamento que não apagou essa mancha de sangue em nossa história.

\section{Notas}

1 Da literatura sobre honra, destacamos a coletânea de Peristiany e Pitt-Rivers (1992) e Peristiani (1971 [1965]). Em português, destaca-se o ensaio bibliográfico "Para que serve o conceito de honra, ainda hoje?", de Fabíola Rohden (2006).

2 Para uma critica das teorias sobre a esfera pública como as de Jürgen Habermas e Richard Sennett consulte o elucidativo artigo de Ari Adut (2005).

3 Alinhamo-nos, portanto, à perspectiva teórico-metodológica inaugurada pelos estudos culturais e desdobrada nos saberes subalternos, ou seja, os estudos pós-coloniais e pela teoria Queer, os quais focam na cultura - e em especial em obras artísticas - como arquivo de experiências históricas ignoradas. Sobre estes saberes, consulte Miskolci (2009), Costa (2006) e Adelman (2009).

4 As frentes estratégicas do dispositivo de sexualidade descritas por Foucault eram, além da pedagogia do sexo que exploraremos neste artigo, a saturação do corpo feminino pela sexualidade devido à sua im- portância reprodutiva; a socialização das condutas de procriação e a psiquiatrização do prazer perverso (Foucault, 2007, pp. 99-100).

5 Um estudo sobre as relações entre homens nas Forças Armadas brasileiras do período é encontrado em Beattie (2004).

6 Em pesquisas associadas ao projeto temático Ciências, Literatura e Nação, criamos estudos sobre cada uma destas obras. Sobre Dom Casmurro, ver Miskolci (2009a); a respeito de Bom Crioulo, ver Lara (2009), e sobre O Ateneu, ver Balieiro (2009).

7 Utilizamos aqui o conceito de diferença como relação social, referindo-se "à maneira como [...] é constituída e organizada em relações sistemáticas através de discursos econômicos, culturais e políticos e práticas institucionais" (Brah, 2006. 362).

8 Sobre a formação de uma geração de crítica e contestação ao status quo imperial em 1870, ver Alonso (2002), Ventura (1991) e Schwarcz (1993). Sobre a trajetória de Raul Pompeia e sua relação com esta geração, ver Balieiro (2009).

9 O pensamento darwinista social difundiu diagnósticos deterministas sobre a sociedade do século XIX e, de forma geral, explicava a suposta decadência social como resultado de influências de grupos ou indivíduos desviantes. Sobre o darwinismo social, consulte Hawkins (1997). A respeito de sua recepção brasileira há extensa bibliografia, da qual destacamos Alonso (2002) e Borges (2005).

10 Nas palavras do crítico: "sem exagero diríamos que é o único personagem sem rosto na galeria do Ateneu, já um privilégio, e talvez o único personagem que nunca faz nada, apenas fala, e é certamente o único personagem masculino, adulto, que mantém estreito contato com Sérgio e que nunca recebe deste uma crítica sequer" (Santiago, 2000, pp. 94-95).

11 Antes que um dado natural e evidente, a presunção da normalidade ou patologia é resultado de discursos e práticas sociais. Sobre a questão, ver Miskolci (2005).

12 Borges (2005) ressalta que o termo degeneração se tornou jargão republicano para referir-se pejorativamente às instituições imperiais. James N. Green (2000) demonstra como a associação entre "sexualidade perversa" e Império estavam presentes no período republicano.

13 No estudo clássico sobre o "armário" que funda a teoria Queer reluzem as palavras de Eve Kosofsky Sedgwick: "Ao final do século XIX, quando virou voz corrente - tão óbvio para a Rainha Vitória como para 
Freud - que conhecimento significa conhecimento sexual e segredos, segredos sexuais, o efeito gradualmente reificante dessa recusa significou que se havia desenvolvido, de fato, uma sexualidade particular, distintamente constituída como segredo" (2007, p. 30).

14 Halperin (2002) afirma que antes da invenção médico-legal da homossexualidade, no terço final do século XIX, existia um sistema de hierarquização baseado em padrões de gênero que relegava a posições marginais não todos homens que se relacionavam com outros homens, antes o efeminado e o invertido. A invenção do homossexual teria transformado a compreensão das relações entre homens e instituído uma hierarquia a partir do desejo baseada no binário hetero/homossexual.

15 Desde o saber médico do século XIX, como as teorias do sexólogo austríaco Richard von Krafft-Ebing, o perverso seria o invertido, aquele que carregaria em si atributos de gênero do sexo oposto e práticas sexuais passivas.

16 Segundo Rogério Diniz Junqueira (2007), a heteronormatividade é a matriz, fonte que gera e justifica o preconceito, a discriminação e a violência envolvidas nas expressões de homofobia, as quais costumam se dirigir contra pessoas cujas expressōes de gênero não se enquadram nas normas.

17 Halperin (2000, p. 100) sublinha a persistência histórica, previamente à invenção da categoria homossexual, de laços afetivos íntimos entre homens, particularmente em contextos elitizados.

18 Sobre o conceito de masculinidade hegemônica, ver Kimmel (1998) e Almeida (2000).

19 Sérgio, após os conselhos de Rebelo, se dá conta do quanto deve lutar para não se transformar em um dos "perversos" descritos pelo colega, e afirmar-se viril por meio da violência foi uma das primeiras exigências (cf. O Ateneu, p. 14).

20 Em contraste com questóes "privadas", as quais se inserem na justiça legal, individualista e baseada no critério das provas.

21 Daí, provavelmente, o primeiro ataque de Olavo Bilac nos jornais o ter associado à figura do masturbador, imagem que o emasculava e, também, evocava discursos da época que associavam masturbação adulta e propensão à degeneração sexual ou à loucura. No século XX, nas Cinco Lições de Psicanálise de Sigmund Freud, a masturbação adulta já evocaria suspeitas de homossexualidade.

\section{BIBLIOGRAFIA}

ADELMAN, Miriam. (2009), A voz e a escuta: encontros e desencontros entre a teoria feminista $e$ a sociologia contemporânea. Curitiba, Blucher.

ADUT, Ari. (2005), "A theory of scandal: Victorians, homosexuality, and the fall of Oscar Wilde". American Journal of Sociology, 111 (1): 213-248.

ALMEIDA, Miguel Vale de. (2000), Senhores de si: uma interpretação antropológica da masculinidade. Lisboa, Fim de Século.

ALONSO, Ângela. (2002), Idéias em movimento: a geração 1870 na crise do Brasil Império. São Paulo, Paz e Terra.

ANDRADE, Mário de. (1974), "O Ateneu”. Aspectos da literatura brasileira. 5 ed., São Paulo, Martins, pp. 173-184.

ARARIPE JUNIOR, Tristao de Alencar. (1978), Araripe Junior: teoria, critica e história literária. Org. Alfredo Bosi. Rio de Janeiro/São Paulo, Livros Tecnicos e Cientificos/Edusp, 1978.

BALIEIRO, Fernando de F. (2009), A pedagogia do sexo em $O$ Ateneu: o dispositivo de sexualidade no internato da "fina flor da mocidade brasileira". São Carlos, dissertação de mestrado, Sociologia-UFSCar, mimeo.

BEATTIE, Peter M. (2004), "Ser homem pobre, livre e honrado: a sodomia e os praças nas Forças Armadas brasileiras (1860-1930)", in Celso Castro, Vitor Izecksohn e Hendrik Kraay (orgs.), Nova história militar brasileira, Rio de Janerio, FGV/Bom Texto, pp. 269-299.

BORGES, Dain. (2005) “'Inchado, feio, preguiçoso e inerte': a degeneração no pensamento social brasileiro, 1880-1940”. Trad. Richard Miskolci. Teoria \& Pesquisa, São Carlos, Programa de Pós-Graduação em Ciências Sociais, pp. 43-70.

BOSI, Alfredo. (1978), Araripe Junior: teoria, critica e historia literaria. Rio de Janeiro, Livros Tecnicos e Cientificos.

(1988) "O Ateneu, opacidade e destruição", in Céu, inferno: ensaios de crítica literária e ideológica, São Paulo, Ática, pp. 33-57.

BOURDIEU, Pierre. (2002), A dominação masculina. Rio de Janeiro, Bertrand Brasil. 
BRAH, Avtar. (2006), "Diferença, diversidade, diferenciação". Cadernos Pagu, 26: 329-376.

BROCA, Brito. (1956), Raul Pompeia. São Paulo, Melhoramentos.

BUTLER, Judith.(1999), "Corpos que pesam: sobre os limites discursivos do 'sexo'", in Guacira Lopes Louro, O corpo educado: pedagogias da sexualidade, Belo Horizonte, Autêntica. - (2003), Problemas de gênero: feminismo e subversão da identidade. Rio de Janeiro: Civilização Brasileira.

CAPAZ, Camil. (2001), Raul Pompeia: biografia. São Paulo, Ediouro.

COSTA, Emília Viotti da. (1999), Da monarquia à república: momentos decisivos. São Paulo, Editora da Unesp.

COSTA, Jurandir Freire. (2004), O vestígio e a aura. Rio de Janeiro, Garamond.

COSTA, Sérgio. (2006), Dois Atlânticos. Belo Horizonte, Editora da UFMG.

COUTINHO, Afranio. (1981), "Introdução geral", in Raul Pompeia, Obras, vol. 1: Novelas, Rio de Janeiro, Civilização Brasileira.

FOUCAULT, Michel. (1979), Microfísica do poder. Rio de Janeiro, Edições Graal. (2004), "Sexo, poder e a política da identidade". Verve-Revista do Nu-Sol, 5: 260-277. (2007), História da sexualidade I: A vontade de saber. Rio de Janeiro, Graal.

GREEN, James N. (2000), Além do carnaval: a homossexualidade masculina no Brasil do século $X X$. São Paulo, Editora da Unesp.

HALPERIN, David. M. (2000), "How to do the history of homosexuality". A Journal of Lesbian and Gay Studies, 6 (1): 87-123.

. (2002), How to do the history of homosexuality. Chicago, The University of Chicago Press.

HAWKINS, Mike. (1997), Social-darwinism in European and American thought: nature as a model and nature as threat. Cambridge, Cambridge University Press.

JUNQUEIRA, Rogério Diniz. (2007), "Homofobia: limites e possibilidades de um conceito em meio a disputas" Bagoas, 1 (1). Disponível em <www.cchla.ufrn.br/bagoas/v03n04art09_junqueira.pdf>.
KIMMEL, Michael. (1998), "A produção simultânea de masculinidades hegemônicas e subalternas". Horizontes Antropológicos, 4 (9): 103-117.

LARA, Oswaldo. (2009), Entre o "instinto" e a "falta de hábito": a psiquiatrização da sexualidade em Bom-Crioulo (1895). São Carlos, dissertação de mestrado em Sociologia, USP.

MISKOLCI, Richard. (2005), "Do desvio às diferenças”. Teoria \& Pesquisa, São Carlos, Pós-Graduação em Ciências Sociais, pp. 9-42.

. (2006), "Machado de Assis, o outsider estabelecido". Sociologias, Porto Alegre, Programa de Pós-Graduação em Sociologia, pp. 352377.

. (2009) "A teoria Queer e a sociologia: o desafio de uma analítica da normalização”. Sociologias, Porto Alegre: Programa de Pós-Graduação em Sociologia, 21: 150-182. . (2009a), "O vértice do triângulo: Dom Casmurro e as relações de gênero e sexualidade no fin-de-siècle brasileiro". Revista Estudos Feministas, 17: pp. 547-567.

MISKOLCI, Richard \& PELUCIO, Larissa. (2008), "Aquele não mais obscuro negócio do desejo", in Néstor Perlongher, O negócio do michê: a prostituição viril em São Paulo. São Paulo, Perseu Abramo, pp. 9-36.

OCTAVIO, Rodrigo. (1978), Minhas memórias dos outros. Rio de Janeiro, Civilização Brasileira.

OLIVEIRA, Pedro Paulo. (2004), A construção social da masculinidade. Belo Horizonte, Editora da UFMG.

PERISTIANY, J. G. (1971 [1965]), Honra e vergonha: valores das sociedades mediterrâneas. Lisboa, Fundação Calouste Gulbenkian.

PERISTIANY, J. G. \& PITT-RIVERS, J. (1992), Honor and grace in anthropology. Cambridge, Cambridge University Press.

PERRONE-MOISÉS, Leyla. (1988), “Lautreámont e Raul Pompeia”, in , O Ateneu: retórica e paixão, São Paulo, Brasiliense/ Edusp.

POMPEIA, Raul. (1982), Obras, vol. 5: Escritos políticos, organização de Afrânio Coutinho. Rio de Janeiro, Civilização Brasileira/Oficina Literária Afrânio Coutinho. 
. (1983), O Ateneu: crônica de saudades.

São Paulo, Moderna.

. (1991), Obras, v. 10, organização de Afrânio Coutinho. Rio de Janeiro, Prefeitura Municipal de Angra dos Reis/Oficina Literária Afrânio Coutinho.

. (1997), As joias da coroa. São Paulo, Nova Alexandria.

ROHDEN, Fabíola. (2006), "Para que serve o conceito de honra, ainda hoje?”. Campos, IMS-Uerj, pp. 101-120.

SANTIAGO, Silviano. (2000), "O Ateneu: contradições e perquirições", in , Uma literatura nos trópicos: ensaio sobre dependência cultural, Rio de Janeiro, Rocco.

SCHWARCZ, Lilia Moritz. (1993), O espetáculo das raças: cientistas, instituiçôes e questão racial no Brasil, 1870- 1930. São Paulo, Cia das Letras.

SEDGWICK, Eve Kosofsky. (1985), Between men: English literature and male homossocial desire. Nova York, Columbia University Press. . (2007), "A epistemologia do armário". Cadernos Pagu, 28: 19-54.

SEIDMAN, Steven. (1996), Queer Theory/Sociology. Cambridge, Blackwell.

VENTURA, Roberto. (1991), Estilo tropical: história cultural e polêmicas literárias no Brasil, 1870- 1914. São Paulo, Cia das Letras. 


\section{O DRAMA PÚBLICO DE RAUL POMPEIA: SEXUALIDADE E POLÍTICA NO BRASIL FINISSECULAR}

\section{Richard Miskolci e Fernando de Figueiredo Balieiro}

Palavras-chave: Sexualidade; Público/ privado; Teoria Queer; Raul Pompeia; Homossexualidade.

A partir do suicídio de Raul Pompeia, buscamos compreender como sua trajetória intelectual e política revela relações pouco reconhecidas entre a sexualidade e a esfera pública no contexto brasileiro de fins do século XIX. Autor de O Ateneu (1888), o jovem republicano, desenvolveu uma crítica do Império por meio de uma história dos descaminhos morais que marcavam a formação da elite nacional. Na República, no entanto, Pompeia viu sua obra e seu engajamento político voltarem-se contra ele pela suspeita de uma sexualidade dissidente, o que o ameaçava com a desonra pública. Desenvolvemos uma análise sociológica e histórica que analisa as normas de gênero e sexualidade que compunham o sistema de valores morais em que se davam as relações entre indivíduo e sociedade no Brasil, borrando as elusivas fronteiras entre público e privado, acontecimento histórico e experiência subjetiva.

\section{THE PUBLIC DRAMA OF RAUL POMPEIA: SEXUALITY AND POLITICS IN FIN-DE-SIECLE BRAZIL}

\section{Richard Miskolci and Fernando de Figueiredo Balieiro}

Keywords: Sexuality; Public/private; Queer theory; Raul Pompeia; Homosexuality.

Taking Raul Pompeia's suicide as our starting point, we aim at understanding how his intellectual and political trajectory reveals unimagined relations between sexuality and the public sphere within the Brazilian context at the turn of the $19^{\text {th }}$ century. Author of the novel $O$ Ateneu (1888), the young Republican developed a critique of the Empire through a story about the moral deviance that marked the education of the nation's elites. Pompeia saw his work and his political commitment within the Republican regime turn against himself, resulting from suspicions of a connection between political and sexual dissent that threatened him with public shame. This historical and sociological analysis reconstitutes the gender and sexual norms that made up the moral value system in which relations between individual and society in Brazil unfolded. We analyze Pompeia's drama by erasing the elusive borderlines amongst public and private lives, historical events, and subjective experience.

\section{LE DRAME PUBLIQUE DE RAUL POMPEIA: SEXUALITÉ ET POLITIQUE AU BRÉSIL À LA FIN DU XIXE SIÈCLE}

\section{Richard Miskolci et Fernando de Figueiredo Balieiro}

Mots-clés: Sexualité; Public/privé; Théorie Queer; Raul Pompeia; Homosexualité.

Nous avons, à partir du suicide de Raul Pompeia, cherché à comprendre de quelle façon sa trajectoire intellectuelle et politique dévoile des rapports peu reconnus entre la sexualité et la sphère publique dans le contexte brésilien de la fin du XIXe siècle. L'auteur de O Ateneu (L'Athénée, 1888), jeune républicain, a développé une critique de l'Empire par une histoire des égarements moraux qui marquaient la formation de l'élite nationale. Néanmoins, c'est sous la République que Pompeia a témoigné son œuvre et son engagement politique se tourner contre lui, dû au soupçon d'une sexualité dissidente qui le menaçait du déshonneur public. Nous avons développé un abordage sociologique et historique qui analyse les normes de genre et de sexualité qui composaient le système des valeurs morales dans lesquelles avaient lieu les rapports entre l'individu et la société au Brésil, maculant les frontières élusives entre le public et le privé, entre le fait historique et l'expérience subjective. 